AGNIESZKA LEWKO

Wydziat Pedagogiki i Psychologii

Uniwersytet Ślaski

Katowice
Forum Pedagogiczne 2016/1

Wpłynęło: 16.12.2015 Zatwierdzono do druku: 14.03.2016

\title{
EDUKACJA SEKSUALNA JAKO ELEMENT WSPIERANIA ROZWOJU OSÓB Z NIEPEŁNOSPRAW NOŚCIĄ INTELEKTUALNĄ
}

Streszczenie: W artykule zaprezentowano założenia edukacji seksualnej dla osób z niepełnosprawnością intelektualną na różnych etapach rozwoju, ukazano jej istotę i znaczenie dla prawidłowego funkcjonowania psychospołecznego. Artykuł zawiera również zagadnienia dotyczące rozwoju w kontekście niepełnosprawności intelektualnej oraz opis specyfiki stadiów seksualności u osób z niepełnosprawnością intelektualną. Autorka opisuje mity i stereotypy funkcjonujące w opinii społecznej, a także przedstawia katalog postaw wobec tej kwestii, starając się zaprezentować główne nurty w edukacji i postrzeganiu seksualności osób z tego typu niepełnosprawnością.

Słowa kluczowe: edukacja seksualna, niepełnosprawność intelektualna, wsparcie, rozwój psychospołeczny

„Prawa człowieka związane z seksualnością oferują ramy, obejmujące prawo każdego do edukacji seksualnej. Nikt nie może być dyskryminowany w dostępie do edukacji i informacji, a także do pojmowanej w sposób wszechstronny edukacji seksualnej oraz do informacji niezbędnych i użytecznych umożliwiających stanie się pełnoprawnym obywatelem, a także zapewniających równość w życiu prywatnym, społecznym i politycznym" (Standardy edukacji seksualnej... 2012, s. 21).

\section{Rozwój a niepełnosprawność intelektualna}

Zagadnienia dotyczące szeroko rozumianego rozwoju osób z niepełnosprawnością intelektualną, szczególnie w stopniu głębszym, niejednokrotnie uważane są za niepopularne, budzące dylematy i kontrowersje. Często opinie ludzi niemających bezpośredniej styczności z takimi osobami uwarunkowane są przez mity i stereotypy oraz - nadal funkcjonujące w opinii społecznej - pejoratywnie nacechowane określenia (tj. niedorozwój, upośledzenie, deficyty umysłowe, ociężałość), które w swych założeniach odbierają im prawo do rozwoju w niemal każdej sferze życia 
(przykładem może być mit wiecznego dziecka). Powoduje to negatywne konotacje emocjonalne, ale też stwarza doskonały grunt do uprzedmiotowienia osób niepełnosprawnych, ich dyskryminacji, wzmaga także izolację społeczną, co skutkuje utrwalaniem niebezpiecznych i krzywdzących stereotypów.

Niepełnosprawność intelektualna to termin złożony i trudny do zdefiniowania ze względu na różnorodne przyczyny, obraz kliniczny, dynamikę przebiegu, prognozy oraz charakterystykę indywidualnego funkcjonowania. Wyróżnia się cztery stopnie obniżenia sprawności intelektualnej: lekki, umiarkowany, znaczny i głęboki. Jako pomoc w ich rozróżnianiu wykorzystywany jest iloraz inteligencji. Jednak poziom funkcjonowania poznawczego to nie wszystko - do pozostałych komponentów niepełnosprawności intelektualnej należą zachowania przystosowawcze oraz profile potrzebnego wsparcia. W myśl koncepcji biopsychospołecznej rozszerzono definicję niepełnosprawności o kontekst społeczny, odwołując się do modelu interakcyjnego, w którym deficyty i ograniczenia nie tkwią w samej jednostce, lecz są ulokowane w relacji między nią a społeczeństwem (Bobkowicz-Lewartowska 2011; Luckasson 2002).

Rozwój określić można jako wzajemne powiązanie oraz przeplatanie się ze sobą sfer kształtujących funkcjonowanie fizyczne, psychiczne, społeczne i emocjonalne. Seksualność stanowi jego nieodłączny element, niemożliwy do wyizolowania spośród pozostałych obszarów. Rozwój cechuje ciągłość, lecz nie równomierność - nie zawsze przebiega on w jednakowym tempie i rytmie, jest bowiem uwarunkowany cechami osobniczymi. Dla specjalistów zajmujących się wspieraniem rozwoju ważne jest, aby odbywał się on - w miarę możliwości - jak najbardziej harmonijnie, by w każdej ze sfer funkcjonowania człowieka występował progres, ewentualnie nie było regresu. W procesie rozwoju określone jego fazy i to, w jaki sposób się przez nie przechodzi, wywierają wpływ na stany następne (Hurlock 1985, s. 75 i nast.).

Nadrzędnym celem wszystkich oddziaływań edukacyjnych, kompleksowo wspierających rozwój, powinien być zawsze wzrost zachowań adaptacyjnych podopiecznego. Oznacza to zmianę całościowej organizacji jego zachowania, a nie usprawnianie poszczególnych funkcji. Głównym celem w pracy z osobą niepełnosprawną jest osiągnięcie przez nią optymalnego poziomu rozwoju, pozwalającego na możliwie największą samodzielność i komfort psychiczny jej oraz otoczenia.

\section{Stadia rozwojowe seksualności i ich specyfika u osób $\mathrm{z}$ niepełnosprawnością intelektualną}

Seksualność wyznacza odmienność kobiety i mężczyzny oraz ich ról w społeczeństwie. Decyduje ona o pewnych aspektach funkcjonowania człowieka nie tylko w wymiarze biologicznym - anatomicznym, fizjologicznym, ale także psychospołecznym - określa temperament, ukierunkowuje aktywność, jest źródłem energii witalnej, podstawą zachowań związanych z poszukiwaniem partnera, płodnością, instynktem rodzicielskim. Podlega rozwojowi, bo z upływem czasu zmienia swoje 
funkcje i formy (Gałecki, Bobińska 2013; Kościelska 2004). Warto szeroko rozumieć tę sferę, gdyż poszerza to perspektywę patrzenia na seksualność, nie sprowadza myślenia o niej tylko do cielesności i aktu płciowego. Takie redukcjonistyczne podejście, które ogranicza tę sferę do wymiaru fizycznego, przyczynia się do „pozbawiania” seksualności osób z niepełnosprawnością intelektualną (Parchomiuk 2013). A bez zrozumienia seksualności nie da się opisać i pojąć człowieka, nie da się w ogóle mówić o człowieku (Kościelska 2004).

Procesualne i etapowe ujęcie rozwoju psychoseksualnego wyróżnia różne stadia seksualności człowieka, dzieląc ją na: dziecięcą, młodzieńczą, dorosłą (dojrzałą) i starczą. Poniżej scharakteryzowane zostaną krótko najważniejsze cechy kolejnych faz (Kościelska 2004), z uwzględnieniem kontekstu niepełnosprawności intelektualnej.

Seksualność dziecięca wyraża się przede wszystkim w potrzebie więzi i przynależności do dorosłego człowieka, a także w oczekiwaniu i wyrażaniu afirmacji ciałem (przytulanie, czuły dotyk, pocałunki). Gdy następuje ich deprywacja, może pojawić się nieuzasadniony wstyd, co ma wpływ na późniejszy rozwój psychoseksualny dziecka. Do przejawów spóźnionej dziecięcej seksualności - nierzadko spotykanej u osób z niepełnosprawnością intelektualną - zaliczyć można: dążenie do stałej bliskości z matką, labilność nastroju w zależności od zainteresowania znaczącego dorosłego, przyleganie fizyczne, obłapianie, tulenie się, obnażanie, domaganie się dowodów miłości, niepełną świadomość zróżnicowania stref ciała dostępnych dla kontaktu z obcymi oraz bliskimi (w tym stref erogennych), dziecięcą kokieterię, preferowanie zabiegów pielęgnacyjnych wokół ciała. Należy dodać, że warunkiem przechodzenia do kolejnych stadiów jest wzrost osobowy, pożądanego efektu nie przynosi behawioralne i emocjonalne karanie za zachowania, które są przecież wyrazem najgłębszych i najpierwotniejszych ludzkich potrzeb.

Seksualność młodzieńcza charakteryzuje się odejściem od bezpośredniej relacji z rodzicami i zwróceniem się ku rówieśnikom. Ten klasyczny okres przygotowywania do życia płciowego i rozrodczości ma wiele aspektów: zmienia się ciało i jego niektóre funkcje, mogą powstać problemy związane $\mathrm{z}$ adaptacją do zmian (w tym także w sferze fizycznej), rozpoznaniem ograniczeń własnego ciała i pogodzeniem się z nim. Występują dążenia do uzyskania określonej pozycji w grupie rówieśniczej i zdobycia jej akceptacji, pojawiają się tendencje rywalizacyjne, np. o miejsce w grupie, zachowania zapewniające większy podziw i adorację, najpierw u osób tej samej płci, później przeciwnej, potrzeba podobania się. Charakterystyczne są także napięcia seksualne i rozładowywanie ich w formach zastępczych (sport, walki) bądź redukowanie poprzez czynności seksualne (masturbacja) i fantazje erotyczne, następuje etap szukania wiedzy na temat seksu i erotyki. Warunkiem przejścia z fazy seksualizmu dziecięcego do młodzieńczego od strony psychologicznej jest osiągnięcie takiego poziomu rozwoju osobowego, który pozwala na autonomiczne funkcjonowanie wśród najbliższych i ukierunkowanie uwagi na innych oraz skutkuje chęcią bycia w grupie rówieśniczej. 
Seksualność dojrzała od strony biologicznej to zdolność zdobycia partnera seksualnego, uczestniczenia w prokreacji i opiece nad potomstwem, co w przypadku osób z niepełnosprawnością intelektualną nie zawsze idzie w parze z umiejętnościami, które wynikają z różnego stopnia ograniczeń. U tych osób płodność jest tym słabsza, im głębszy jest stopień niepełnosprawności i większe jego zdeterminowanie przez czynniki genetyczne.

Seksualność starcza - najprościej ujmując - to taka, w której zgodnie z tradycyjnym myśleniem seks już jest biologicznie zbędny, a psychologicznie nie budzi zainteresowania.

W przypadku części osób z niepełnosprawnością intelektualną rozwój psychoseksualny odbywa się z pominięciem fazy dojrzałej seksualności (często też młodzieńczej). Może to być podyktowane niewystarczającym rozwojem popędu seksualnego lub wyparciem potrzeb seksualnych, które w tym przypadku chroni przed świadomością niemożności realizacji własnego potencjału oraz przed odpowiedzialnością za własną seksualność.

Wszystkie wymienione stadia rozwoju psychoseksualnego mogą występować w populacji osób z niepełnosprawnością intelektualną, mają jednak pewne specyficzne cechy. Poszczególne etapy najczęściej pojawiają się później niż u rówieśników w normie intelektualnej (im głębszy stopień niepełnosprawności - tym jest to bardziej przesunięte w czasie) (Kijak 2010, za: Otrębski, Czusz 2013), obserwuje się też zatrzymanie na określonym stadium (fiksacja czasowa lub stała) lub trwanie z jednoczesnym występowaniem cech kilku faz. Rozwój psychoseksualny może także przebiegać w sposób niepełny bądź nadmiernie zaznaczony, bywa też niewłaściwie ukierunkowany.

Zjawiskiem, które można uznać za charakterystyczne dla osób z niepełnosprawnością intelektualną, jest brak harmonii (zrównoważenia) pomiędzy tempem rozwoju w poszczególnych sferach: biologicznej, umysłowej, uczuciowej, duchowej i behawioralnej (m.in. Kościelska 2004). Przy czym warto zauważyć, że odchylenia w najmniejszym stopniu dotykają sfery biologicznej (w porównaniu z populacją osób pełnosprawnych) - rozwój bioseksualny przebiega zgodnie z wzorcami występującymi u osób pełnosprawnych (Mejnartowicz 2005, za: Otrębski, Czusz 2013). Przechodzenie $z$ jednej fazy w drugą umożliwia wgląd w te słabości procesu rozwojowego, które wymagają wsparcia i należą do specyfiki osób z niepełnosprawnością (Kościelska 2004).

\section{Obraz seksualności osób z niepełnosprawnością intelektualną - edukacja dla społeczeństwa}

Jak wcześniej wspomniano, w przekazie społecznym osadzone są (czasem głęboko zakorzenione - stanowiąc utrudnienie dla terapeutów i edukatorów) mity i stereotypy dotyczące osób z niepełnosprawnością intelektualną, nie omijają one też sfery seksualności (kilka z nich zostanie tutaj omówionych). Poza tym tematyka ta 
w kontekście niepełnosprawności stanowi swoiste tabu społeczne: „największym problemem dotyczącym seksualności i zaspokajania potrzeb seksualnych osób niepełnosprawnych w Polsce jest to, że w ogóle nie widzi się tego problemu i nie ma zrozumienia i akceptacji dla potrzeb tych ludzi. Omija się ten temat - podkreśla prof. Zbigniew Lew Starowicz" (Stanisławski 2004, s. 15).

Jeden z mitów odnosi się do wizerunku wiecznego dziecka, wiąże się on z ograniczaniem (w percepcji społecznej) możliwości rozwoju osób z niepełnosprawnością intelektualną, pomimo że mają one coraz więcej lat. Ich infantylizacja nie dotyczy tylko sfery seksualności, bo często wynika z kreowanego wizerunku. Dorosłe osoby ubierane jak dzieci, posiadające dziecięce atrybuty (lalki, kokardy, kolorowe czapeczki, odzież w zbyt małym rozmiarze, buty z rzepami, spodnie dresowe łączone z elegancką koszulą), do których zwraca się nie dość, że po imieniu (robią to nawet osoby nieznajome), to jeszcze używając zdrobnień (pięćdziesięcioletni „Krzysiu”, trzydziestoparoletnia „Renatka”)... W związku z tym mamy tendencję do przypisywania im cech rozwojowych charakterystycznych dla wieku dziecięcego, pozbawiając ich tym samym prawa do seksualności.

Blisko mitu wiecznego dziecka sytuuje się pogląd o aseksualności osób z niepełnosprawnością intelektualną. Opiera się on na przekonaniu, że skoro istnieją u nich deficyty poznawcze, to nie są one zdolne do odczuwania emocji, odbierania wrażeń seksualnych, wobec czego nie mają prawa do wyrażania swoich potrzeb. Dlatego często sfera seksualna jest w wychowaniu pomijana, traktowana ad hoc lub nieobecna. Pozbawianie seksualności osób z niepełnosprawnością intelektualną wynikać może także z podejścia redukcjonistycznego, które istotę tej sfery sprowadza do wymiaru fizycznego.

Kolejny mit demonizuje seksualność osób z niepełnosprawnością intelektualną, bazując na przekonaniu o ich całkowitym braku kontroli nad sobą - także w tej sferze. W tym micie zakłada się, że, owszem, seksualność istnieje, lecz manifestuje się poprzez dewiacyjne formy zachowań (osoby z niepełnosprawnością jako sprawcy przestępstw, nadużyć, realizujący swoje potrzeby seksualne w sposób naruszający powszechne zasady współżycia społecznego, np. poprzez ekshibicjonizm).

Hiperseksualność to kolejna cecha przypisywana często ogółowi osób z niepełnosprawnością intelektualną, ich popęd opisuje się jako kompulsywny i niedający się opanować (częsta masturbacja, obnażanie się w miejscach publicznych, akty homoseksualne). Seksualność postrzegana jest tu w kontekście pewnej manii, a pożądanie traktowane jest jako niezmienna stała cecha.

Wachlarz postaw wobec seksualności jest więc bardzo szeroki: od afirmacji, permisywności do poglądów skrajnie konserwatywnych, pozbawiających osoby z niepełnosprawnością intelektualną seksualności, gdzieś pomiędzy nimi znajdziemy unikanie poruszania tego tematu (tabu, mechanizm odrzucenia) czy ograniczanie (np. tylko do poziomu seksualności dziecięcej u osób dorosłych). Opisane wcześniej strategie są implikowane następującymi, opisanymi w literaturze, postawami wobec płciowości, o których z powodzeniem można mówić w kontekście niepełnosprawności intelektualnej: 
- rygorystyczną i tradycjonalistyczną,

- zdezorientowania i bezradności,

- pasywności (Kozakiewicz 1969; por. Kościelska 2004).

W związku ze złożonością społecznych nastawień wyróżniono także inne postawy wobec seksualności osób z niepełnosprawnością intelektualną (niestety, w głównej mierze o nacechowaniu pejoratywnym), polegające na jej ignorowaniu, udaremnianiu, tolerowaniu i akceptowaniu (Kościelska 2004), czy też - zgodnie $\mathrm{z}$ inną koncepcją - totalnym akceptowaniu, deseksualizacji i unikaniu oraz sublimacji (Nowak-Lipińska 1996). W Polsce w dalszym ciągu zbyt rzadko porusza się temat potrzeb seksualnych osób z niepełnosprawnościami, sporadycznie i raczej okazjonalnie rozmawia się o tym z nimi samymi. Panuje mylne przekonanie, że rozmowa na "te tematy” niepotrzebnie tylko rozbudzi ich aktywność i zainteresowanie seksem (Stanisławski 2004), brakuje natomiast świadomości, że tłumienie tych potrzeb może powodować powstanie takich problemów jak agresja.

Nieobecność edukacji do niepełnosprawności, brak osobistej styczności z osobami z niepełnosprawnością, niewystarczające uświadomienie społeczne czy infantylizacja niepełnosprawności intelektualnej mogą sprawić, że obraz seksualności osób z niepełnosprawnością intelektualną będzie spaczony (m.in. Maison 2008). Jednak bardziej niepokojący wydaje się fakt, że sami rodzice i opiekunowie takich osób mają w tym zakresie braki. Okazuje się bowiem, że zaledwie 3,8\% rodziców akceptuje to, że ich dzieci z niepełnosprawnością intelektualną stają się w pewnym momencie istotami seksualnymi, $\mathrm{z}$ kolei aż $37,4 \%$ przyjmuje wobec tego faktu postawę odrzucenia (Kijak 2014).

\section{Edukacja seksualna - szanse i założenia procesu wspierania}

Refleksjom dotyczącym edukacji seksualnej często towarzyszą obawy przed nadmiernym rozbudzeniem popędu i przedwczesnej aktywności w tym zakresie. Związane jest to ze wspomnianym już redukcjonistycznym podejściem do seksualności, sprowadzającym ją do wymiaru wyłącznie fizycznego (biologicznego, prokreacyjnego), a przy tym przesiąkniętym wieloma mitami i charakterystycznymi nastawieniami. Poniekąd ma to charakter błędnego koła, gdyż w czasie wychowania „urabia się" osoby z niepełnosprawnością, „wtłacza się” je w wykreowany obraz, co z kolei powoduje, że funkcjonują one zgodnie z oczekiwaniami otoczenia, nie wykorzystując własnych możliwości rozwojowych, swojego indywidualnego potencjału (niejednokrotnie sprawiając wrażenie bardziej niepełnosprawnych, niż rzeczywiście są).

Podobne rozważania dotyczą seksualności w kontekście niepełnosprawności intelektualnej w percepcji najbliższego otoczenia, w tym rodziców/opiekunów (por. Fornalik 2004, 2012; Kościelska 2004; Nowak-Lipińska 1996 i in.), co obrazują słowa dr Izabeli Fornalik, praktyka z zakresu edukacji seksualnej: „Seksualność i osoby z niepełnosprawnością intelektualną? To połączenie budzi często wiele 
wątpliwości, a niekiedy przeświadczenie, że przecież seksualność nie dotyczy mojego dziecka czy wychowanka, bo... jest jeszcze małym dzieckiem, bo jest głęboko niepełnosprawny intelektualnie, bo przecież nie będzie uprawiać seksu, nie będzie mieć żony, męża, nie założy rodziny... A przecież seksualność to coś więcej niż uprawianie seksu" (Fornalik 2012, s. 4).

Tę ostatnią myśl pragnę uczynić przewodnią w moich rozważaniach o edukacji osób z niepełnosprawnością intelektualną z zakresu seksualności. W praktyce pedagogicznej, rehabilitacyjnej często poszukujemy argumentów uzasadniających seksualność - w rozmowach $\mathrm{z}$ rodzicami/opiekunami, $\mathrm{z}$ otoczeniem społecznym, urzędnikami czy przedstawicielami instytucji. A tymczasem każdy opiekun i terapeuta obserwuje u swojego podopiecznego rozwój - osoba ta zmienia się pod względem fizycznym, emocjonalnym i intelektualnym, nabywa nowych cech i umiejętności. Rozwój każdego człowieka determinują z jednej strony mechanizmy biologiczne, ale z drugiej wpływy środowiska - otoczenia i wszystkich jego bodźców. Niepełnosprawność intelektualna sama w sobie nie czyni człowieka istotą aseksualną, podobnie jak inne ograniczenia w zdrowiu i sprawności. Antoni Bartoszek podkreśla, że „człowiek niepełnosprawny, jak każda inna istota ludzka, jest jednością duchowo-psychofizyczno-cielesną, ma on także prawo do dojrzałego i pogłębionego przeżywania własnej seksualności” oraz „człowiek niepełnosprawny, będąc bądź też mężczyzną, bądź też kobietą, zachowuje swoją osobową godność niezależną ani od płci, ani od niepełnosprawności" (Bartoszek 2009, s. 76-77).

W literaturze z zakresu pedagogiki specjalnej, ale także w Konwencji ONZ o prawach osób niepetnosprawnych czy europejskich standardach edukacji seksualnej wysuwane są postulaty podnoszące konieczność normalizacji życia seksualnego takich osób, w tym edukowania i wychowania do seksualności. Obejmują one:

- uznanie prawa osób z niepełnosprawnością do wyrażania swej seksualności, czerpania z niej satysfakcji i radości,

- uznanie prawa niepełnosprawnych do miłości i tworzenia związków,

- konieczność prowadzenia wychowania seksualnego dzieci i młodzieży niepełnosprawnej niezależnie od stopnia niepełnosprawności,

- konieczność przygotowania specjalistów, którzy zajęliby się wychowaniem seksualnym w placówkach kształcenia specjalnego oraz edukowaniem rodziców i opiekunów osób z niepełnosprawnością (Fornalik 2004, s. 135).

Na kanwie tych założeń warto zbudować programy edukacji seksualnej i określić, co będzie treścią nauczania/wychowania - poszerzając ramy tematyczne i odchodząc od redukcjonistycznego podejścia do płciowości/seksualności. Warto przypomnieć w tym miejscu o kilku przesłankach prawidłowej edukacji uczniów z niepełnosprawnością intelektualną. Jedną z podstawowych jest zasada indywidualizacji, wyrażająca się w dostosowaniu treści, metod i środków zarówno do potrzeb, jak i możliwości podopiecznego. W aspekcie edukacji seksualnej można odnieść to do uwzględniania etapów rozwojowych oraz logicznego i transparentnego przedstawiania treści (odpowiednie słownictwo, dobór materiału do aktualnego stanu 
rozwoju, zakaz wprowadzania treści na siłę, gdy nie są potrzebne), tak aby uniknąć niezrozumienia czy poruszania nieadekwatnych zagadnień.

Kolejnym założeniem w edukacji seksualnej jest zasada holistycznego podejścia do podopiecznego. Odnosi się ona do percepcji jego samego przy założeniu, że człowiek jest jednostką funkcjonującą równocześnie w sferze biologicznej, psychologicznej i społecznej (każda ze sfer jest zależna od pozostałych) - co wiąże się $\mathrm{z}$ dążeniem do harmonijności rozwoju. Ma to odzwierciedlenie w szerokim rozumieniu pojęcia seksualności - odnoszonego do różnych aspektów życia człowieka: fizycznego, społecznego, interpersonalnego, ale również poznawczego i emocjonalnego (a także wspieraniu jednostki w takim wieloaspektowym rozwoju).

Całościowe rozumienie rozwoju osoby i specyfiki jej funkcjonowania w stanie niepełnosprawności intelektualnej generuje konieczność integralnego kształcenia. Oznacza to, że treści edukacyjne z zakresu seksualności powinny w jak największym stopniu zostać wplecione w pozostałe, być realizowane systematycznie (w trakcie codziennych zajęć, czynności) i w miarę możliwości koedukacyjnie (oczywiście z wyłączeniem zajęć przewidzianych jako osobne, np. z higieny dojrzewania). Drogi realizacji tych treści także powinny tworzyć jednolitą całość, umożliwiając łączenie teorii z praktyką (kształtowanie nawyków, uczenie się poprzez obserwację).

Ważnym założeniem w procesie wspierania rozwoju i szansą na jego powodzenie jest przygotowanie na możliwe trudności bądź zniwelowanie negatywnych skutków przeżywanych niepowodzeń. Stąd także wynika potrzeba edukacji seksualnej osób z niepełnosprawnością intelektualną, które często odczuwają niepokój w związku ze zmianami w okresie dojrzewania płciowego. Cel wychowania do seksualności to zatem akceptacja zmian (przede wszystkim nabywanie tożsamości płciowej), ograniczenie lęku i obaw, które są z nimi związane, wprowadzenie rzetelnej i dostosowanej do poziomu rozumienia wiedzy, ukazanie naturalności procesu dorastania.

Obecnie, w procesie właściwego wspierania rozwoju seksualności, znaczenia nabiera wprowadzanie w tej sferze prawidłowego nazewnictwa. Nasycone wulgarnością przekazy medialne, łatwy dostęp do mediów, a często także brak edukacji seksualnej czy jej samorzutność („uczenie się” od rówieśników) niosą wiele zagrożeń, takich jak: promiskuityzm, zniekształcony, wypaczony obraz kobiet i mężczyzn, nieodpowiednie słownictwo (które niejednokrotnie powoduje brak zrozumienia w przypadku konfrontacji ze sformułowaniami naukowymi, neutralnymi) czy - znana z mitów - hiperseksualność, nadmierne pobudzenie erotyczne. Z mojego doświadczenia ${ }^{1}$ wynika, że edukacja seksualna, poprzedzająca styczność z niewłaściwym przekazem, oraz obecność osoby wspierającej, edukatora, któremu można zadać wszystkie pytania, często powodują, że dzieci i młodzież czują się

${ }^{1}$ Doświadczenie w toku zajęć edukacyjno-profilaktycznych z zakresu seksualności w koedukacyjnej grupie integracyjnej (integracyjna świetlica środowiskowa), w tym z dziećmi i młodzieżą $\mathrm{z}$ niepełnosprawnością intelektualną w stopniu lekkim i umiarkowanym. 
bezpieczniej i pewniej ze swoją seksualnością, a także rzadziej ulegają w tej kwestii presji medialnej czy rówieśniczej.

Nie mniej ważnym, choć niestety często pomijanym zagadnieniem jest profilaktyka medyczno-zdrowotna, tak ważna dla kompleksowego wspierania rozwoju nie tylko osób z deficytami poznawczymi. Niedostatki w przyswojeniu nawyków higienicznych, nieuzasadniony strach przed wizytą u lekarza, nieumiejętność rozpoznawania podstawowych stanów chorobowych i brak znajomości sposobów niwelowania dyskomfortu, który im towarzyszy, to bolączki, z którymi borykają się nie tylko osoby z niepełnosprawnością intelektualną, ale także ich rodzice/ opiekunowie. Wskazuje to na konieczność wielotorowego realizowania działań edukacyjnych i skierowania wsparcia do samych podopiecznych oraz ich rodzin, a nawet oddziaływania na świadomość społeczną poprzez działalność profilaktyczną o charakterze uniwersalnym.

Aby wsparcie osób z niepełnosprawnością intelektualną było efektywne, należy zadbać o jednolity front rehabilitacyjno-wychowawczy, czyli głębokie porozumienie między placówką a rodzinami w kwestii poruszanych treści, przyjętych zasad czy poszanowania intymności. Choć niejednokrotnie zadanie to nie należy do najłatwiejszych, to dla osiągnięcia długofalowych efektów, celów związanych z poszerzeniem autonomii i osiągnięciem optymalnego poziomu rozwoju, warto ten wysiłek podjąć. To od opiekunów/rodziców w dużej mierze zależy, czy osoba $\mathrm{z}$ niepełnosprawnością intelektualną otrzyma wsparcie $\mathrm{w}$ dążeniu do kolejnych etapów swojego rozwoju oraz jak poradzi sobie z wyzwaniami, jakie ten rozwój przyniesie.

Jak już wcześniej wspomniano, założenie, że człowiek jest jednością biopsychospołeczną, poszerza perspektywę wychowania do seksualności o sfery emocjonalną i społeczną. Zatem zakres tematyczny obejmować powinien zagadnienia takie jak: różne odcienie miłości i sposoby jej realizacji, formy okazywania uczuć, cechy dobrego związku, dylematy związane z podjęciem współżycia (wiedza na temat tego, czym jest i jakie niesie konsekwencje - rozważenie, czy nie kryje się za nim potrzeba bliskości, czułości, akceptacji...).

Na podstawie powyższych rozważań i doświadczeń praktycznych można sformułować hasła, dotyczące ogólnych, najbardziej podstawowych warunków sprzyjających realizacji edukacji seksualnej osób z niepełnosprawnością intelektualną:

- efektywna edukacja to edukacja rozpoczęta jak najwcześniej;

- pojmowanie człowieka jako istoty, którą cechuje jedność biopsychospołeczna (zagadnienie seksualności realizowane wielotorowo - z niemożliwą do wyizolowania żadną ze sfer);

- specyficzne i rozszerzone treści (np. w sferze kształtowania nawyków higienicznych);

- wychowanie seksualne prowadzone holistycznie i wielowymiarowo, również poza szkołą. 
Populację osób z niepełnosprawnością intelektualną charakteryzuje stosunkowo niski poziom wiedzy na temat zagadnień związanych z płciowością i dążenia do jej zdobywania. Stan ten jest rezultatem braku konsekwentnie prowadzonej edukacji seksualnej wobec dzieci i młodzieży z niepełnosprawnością, a także dorosłych (Nowak-Lipińska 1996).

Wspieranie osób z niepełnosprawnością intelektualną w realizowaniu ich seksualności, z uwzględnieniem wymienionych założeń, przyczynić się może do ich integralnego rozwoju, wyrażającego się w zachowaniu godności, poczuciu tożsamości osobowej, autonomii psychicznej i społecznej (Parchomiuk 2009, s. 31). Odpowiednio prowadzona edukacja seksualna może wspomagać wszechstronny rozwój, a nabywanie wiedzy i umiejętności pomóc uchronić, zmniejszyć lub zniwelować prawdopodobieństwo negatywnych przeżyć i doświadczeń. Osoby uczestniczące w edukacji seksualnej stają się bardziej świadome w kwestii własnej płciowości, dzięki czemu ujawniają ją w sposób akceptowany społecznie. Z pewnością szersze spojrzenie na walory edukacji seksualnej pozwala dostrzec jej zalety w perspektywie społecznej.

\section{Bibliografia}

Bartoszek A. (2009). Seksualność osób niepełnosprawnych: studium teologiczno-moralne, Katowice: Księgarnia św. Jacka.

Bobkowicz-Lewartowska L.(2011). Niepełnosprawność intelektualna. Diagnozowanie, edukacja i wychowanie. Warszawa: Harmonia.

Fornalik I. (2004). Osoby niepetnosprawne - niektóre właściwości rozwoju i funkcjonowania seksualnego człowieka. W: Kościelska M., Aouil B. (red.). Człowiek niepetnosprawny - rodzina i praca. Bydgoszcz: Wydawnictwo Akademii Bydgoskiej.

Fornalik I. (2012). Przełamać tabu. „Społeczeństwo dla Wszystkich”, nr 4 (46), s. 4-5.

Gałecki P., Bobińska K. (2013). Seksualność osób niepetnosprawnych intelektualnie. „Medycyna po Dyplomie”, nr 9, s. 12-16.

Hurlock E.B. (1985). Rozwój dziecka. T. 1. Warszawa: PWN.

Kijak R. (2014). Seksualność człowieka z niepełnosprawnościa intelektualna a rodzina. Warszawa: Wydawnictwo Lekarskie PZWL.

Kościelska M. (2004). Niechciana seksualność: o ludzkich potrzebach osób niepełnosprawnych intelektualnie. Warszawa: Wydawnictwo Jacek Santorski.

Kozakiewicz M. (1987). Różne odmiany wychowania seksualnego. W: Kozakiewicz M., Lew-Starowicz Z. (red.). Przysposobienie do życia $w$ rodzinie. Warszawa: Wydawnictwo Lekarskie PZWL.

Kozakiewicz M. (1969). U podstaw wychowania seksualnego w szkole. Warszawa: Wydawnictwo Lekarskie PZWL.

Luckasson R. (red.). (2002). Mental retardation. Definition, classification, and systems of supports. Washington: American Association on Mental Retardation. 
Maison D. (2008). Postrzeganie osób upośledzonych umysłowo przez społeczeństwo polskie. Raport z badania ilościowego i jakościowego. Warszawa: Dom Badawczy Maison.

Nowak-Lipińska K. (1996). O ignorancji sfery erotycznej osób głębiej upośledzonych umysłowo. W: Kawula S., Machel H. (red.). Młodzież a współczesne dewiacje i patologie społeczne. Wyd. 1. Toruń: Wydawnictwo Adam Marszałek.

Otrębski W., Czusz A. (2013). Osoby z niepetnosprawnościa intelektualna wobec własnej seksualności. W: Kijak R. (red.). Seksualność - niepełnosprawność rzeczywistość: współczesne konteksty badawcze w problematyce seksualności człowieka $z$ niepełnosprawnościa. Warszawa: Garmond.

Parchomiuk M. (2009). Edukacja seksualna osób z niepełnosprawnościa intelektualna. „Człowiek - Niepełnosprawność - Społeczeństwo”, nr 1 (9), s. 23-36.

Parchomiuk M. (2013). Seksualność osób z niepełnosprawnościa intelektualna w personalistycznym ujęciu Jeana Vaniera i Antoniego Bartoszka. „Społeczeństwo i Rodzina", nr 34, s. 55-70.

Standardy edukacji seksualnej w Europie (2012). Federalne Biuro ds. Edukacji Zdrowotnej (BZgA) i Biuro Regionalne Światowej Organizacji Zdrowia dla Europy (WHO). Lublin: Wydawnictwo Czelej.

Stanisławski P. (2004). Seks upośledzany. „Integracja”, nr 4, s. 14-18.

\title{
SEX EDUCATION AS AN ELEMENT OF SUPPORTING PEOPLE WITH INTELLECTUAL DISABILITIES
}

\begin{abstract}
The article presents the assumptions of sexual education for people with intellectual disabilities in different stages of human development, revealing its essence and importance for the proper psychosocial functioning of these people. The article contains also development issues in the context of intellectual disability, a description of the specifics of stages of sexuality in these individuals. Moreover, the author characterizes myths and stereotypes functioning in public opinion and presents a catalogue of attitudes towards this issue, trying to present the main trends in education and perception of sexuality of people with intellectual disabilities.
\end{abstract}

Key words: sexual education, intellectual disability, support, psychosocial development

Agnieszka Lewko - magister pedagogiki, asystent naukowo-dydaktyczny w Zakładzie Pedagogiki Specjalnej Wydziału Pedagogiki i Psychologii Uniwersytetu Śląskiego w Katowicach. Redaktorka monografii Sprawni niepetnosprawni na rynku pracy. Możliwości i szanse zawodowe osób z niepełnosprawnością (2013) i współredaktorka książki Tradycja i nowoczesność - funkcjonowanie osób z niepełnosprawnościa we współczesnym świecie (2013). Adres do korespondencji: Uniwersytet Śląski, Wydział Pedagogiki i Psychologii, Zakład Pedagogiki Specjalnej, ul. Grażyńskiego 53, 40-126 Katowice. Adres e-mail: agnieszka-lewko@o2.pl. 